Editorial

\title{
The relevance of psychoanalysis to the understanding of parental alienation
}

Volume I Issue 5 - 2014

\section{Editorial}

While conflict between parents seeking divorce is commonplace, it sometimes intensifies to the point that agreement cannot be reached even on the most basic issues. The effect of such discord often has a devastating impact on their children. In such families, there is often no safe haven, no way to maintain a positive relationship with one parent without jeopardizing the child's relationship with the other parent. When the child is made to feel that his or her relationship with the aligned parent depends on rejecting the relationship with the other parent, the term parental alienation is appropriate.

While transient symptoms of parental alienation are virtually unavoidable in any divorce, the psychoanalytically-informed custody evaluator bears the responsibility of offering an opinion on the reasonableness of the child's feeling on the basis of the behavior of the nonaligned parent or whether he or she is the victim of a deliberate strategy on the part of the aligned parent to undermine the relationship. No easy task, the clinician must be ready to utilize all of his or her listening skills as to gather evidence from multiple sources to insure that all hypotheses have been considered.

\section{Dissociation of moral values}

It is nevertheless the case that parental alienation poses the dilemma of explaining how children can feel intense animosity toward a parent who previously has been loved. How does love become twisted into its opposite? One clue is found in the work of Johnson and Szurek ${ }^{1}$ who discovered that delinquent children sometimes transgress based on identifications with a parent, taking pleasure from acting on forbidden wishes tacitly, sometimes unconsciously, encouraged. Not only does such encouragement lead children to believe their actions are permissible, but also that they are virtuous, undoing unarticulated harms experienced by the aligned parent. In this scenario, hostility toward one parent is an expression of loyalty and love toward the other.

\section{The psychoanalytically-informed evaluator and the court}

When parental alienation is identified, it is accorded great weight in custody decision. A parent who actively alienates a former spouse is unlikely to be acting in his or her child's best interests. That being said, the relationship between parental behavior and the child's subjective experience is complex and multifactorial. Indeed, it is often the case that alienating behavior of the part of the aligned parent is an

\author{
Ronald C Naso \\ American Board and Academy of Psychoanalysis, USA
}

Correspondence: Ronald C Naso,American Board and Academy of Psychoanalysis, 2777 Summer Street, Suite 504B, Stamford, CT 06905, USA, Tel 203-325-366I, Fax 203-325-0I45, Email rcnphd@gmail.com

Received: September 18, 2014 | Published: September 20, 2014

insufficient condition parental alienation. This conclusion is based on the observation that whereas alienating behavior is common in high conflict divorces, parental alienation proper occurs in a relatively small proportion of cases. There can be many reasons for children's animosity. As a result, Kelly and Johnson ${ }^{2}$ argue that a finding of parental alienation should satisfy the following three criteria: (a) the child's hatred is new; (b) irrational, which is to say, not supported by the past or present behavior of the parent; and (c) does not occur in the context of parental abuse, neglect, and/or mistreatment (or in the effort to establish such claims). Appreciating the context and complexity of the motives undergirding this phenomenon positions the psychoanalyst to decipher the full array intra- and interpersonal factors that prompting alienation and educate the Court about its impact on the child. Contextualizing the child's emotions and beliefs developmentally as well as within the dynamics of the family offers information vital to reaching solutions that are in the child's best interests.

\section{Acknowledgments}

None.

\section{Conflicts of interest}

Author declares there are no conflicts of interest.

\section{Funding}

None.

\section{References}

1. Johnson AM, Szurek SA. The genesis of antisocial acting out in children and adults. Psychoanal Q. 1952;21(3):323-343.

2. Kelly JB, Johnson JR. The alienated child: A reformulation of parental alienation syndrome. Family Court Review. 2001;39(3):249-266. 